\title{
LITERATUR KEISLAMAN DALAM PENDIDIKAN PONDOK PESANTREN (Studi di Madrasah Diniyah Nurul Islam Dasan Baru, Murbaye, Lombok Tengah)
}

\author{
Rohana, Widiastuti Furbani, Iwin Ardyawin \\ D3 Perpustakaan, Universitas Muhammadiyah Mataram \\ rohana.mip@gmail.com
}

\section{INFO ARTIKEL}

Riwayat Artikel:

Diterima:10-10-2017

Disetujui: 20-12-2017

\section{Kata Kunci:}

Literatur keislaman Metode Pembelajaran Pondok Pesantren

\section{A. LATAR BELAKANG}

Secara historis pesantren merupakan sistem pendidikan Islam paling awal yang tumbuh sejak awal kedatangan Islam di Indonesia [1]. Disinyalir sebagai pendidikan yang lahir dan tumbuh melalui kultur Indonesia yang bersifat "indogenous" dan diyakini oleh sebagian kalangan telah mengadopsi model pendidikan sebelumnya yaitu dari pendidikan Hindu dan Budha sebelum kedatangan Islam [2]. Sistem pendidikan ini diidentikkan dengan kuttab [3], di mana seorang kyai mengajari santri dengan sarana masjid sebagai tempat pengajaran / pendidikan, dan di dukung oleh pondok sebagai tempat tinggal santri.

Alasan pokok munculnya pesantren ini adalah untuk mentransmisikan Islam tradisional sebagaimana yang terdapat dalam kitab kitab klasik yang ditulis berabad abad yang lalu.Kitab kitab ini dikenal di Indonesia sebagai kitab kuning. Jumlah teks klasik yang diterima di pesantren sebagai ortodoks (al-kutub al-mu'tabarah) pada prinsipnya terbatas [4].

Dalam kebanyakan pesantren terutama di Lombok,sebagai proses awal membangun sebuah pesantren dimulai dahulu dengan membangun 
madrasah Diniyah. Sistem ini tentu identik dengan sistem pembelajaran pada pendidikan islam awal yaitu dengan sarana masjid atau aula khusus sebagai tempat pengajaraan,cara si santri yang membaca kitab,sementara kyai mendengar sekaligus mengoreksi kalau ada kesalahan [5].

Madrasah Diniyah sebagai pendidikan Islam non formal memiliki keunikan tersendiri dibanding madrasah / sekolah formal. Pola pendidikan dan pengajarannya erat kaitannya dengan tipologi pondok pesantren maupun cirri-ciri (karakteristik) pondok pesantren itu sendiri. Umumnya pesantren di Lombok maupun di luar Lombok menggunakan beberapa system pendidikan dan pengajaran yang bersifat tradisional. Yakni system yang bersifat sederhana seperti pola pengajaran sorogan, bandongan, wetonan, dan musyawarah dalam mengkaji kitab-kitab agama yang ditulis oleh para ulama zaman abad pertengahan, di mana kitab-kitab itu kita kenal dengan sebutan "kitab kuning" [6].

Madrasah Diniyah Nurul Islam Dasan Baru Murbaye mempunyai andil besar dalam mentransmisikan ajaran Islam tradisional sebagaimana yang diajarkan oleh ulama-ulama terdahulu. Dalam hal ini Madrasah Diniyah berfungsi sebagai tempat pembelajaran agama Islam yang sifatnya masih dasar namun mampu memberi pemahaman Islam secara baik terutama untuk kehidupan sehari-sehari. Hal ini merupakan jawaban atas tuntutan para orang tua santri yang ingin melihat anaknya paham atau mengerti ilmu-ilmu agama terutama untuk membendung anak-anak dan remaja dari arus modernisasi dan globalisasi yang semakin menggerus nilai-nilai normativitas anak.

Literatur Islam yang digunakan dalam konteks pondok pesantren umumnya berupa literature klasik, baik untuk literatur fiqh, tafsir, hadits, bahasa, aqidah akhlak, tasawuf, dan sebagainya.Umumnya literature klasik tersebut dikarang oleh ulama-ulama Arab dan sebagian dari ulama nusantara.Literatur klasik yang biasa disebut kitab kuning ini menjadi pegangan pertama walaupun zaman semakin modern dan telah banyak literature keislaman kontemporer.

Khazanah Islam kontemporer yang mewarnai literature keislaman di pondok pesantren khususnya di Madrasah Diniyah Nurul Islam tidak mesti membuat literatur yang biasa dipakai ditinggalkan.Hal ini menjadi perhatian khusus penulis dalam meneliti lebih dalam mengenai literatur keislaman di pondok pesantren dan bagaimana metode pembelajaran yang diterapkan di dalam memahami literatur keislaman di pondok pesantren. Dalam hal ini rumusan masalah yang penulis dapatkan adalah:

1. Literatur-literatur apa saja yang digunakan di Madrasah Diniyah Pondok Pesantren Nurul Islam, Dasan Baru, Murbaye?

2. Bagaimana metode pembelajaran yang diterapkan dalam memahami literature-literatur keislaman di Madrasah Diniyah Nurul Islam, Dasar baru, Murbaye.

Sedangkan tujuan penelitian ini secara ringkas adalah:

1. Untuk mengetahui literatur-literatur yang digunakan di madrasah Diniyah Pondok Pesantren Nurul Islam, Dasan Baru, Murbaye

2. Untuk mengetahui metode pembelajaran yang diterapkan dalam memahami literature-literatur keislaman di madrasah Dniyah Nurul Islam, Dasan Baru, Murbaye.

\section{B. LANDASAN TEORI}

\section{Pondok pesantren}

a. Pengertian pondok pesantren

Di Indonesia, istilah pesantren lebih popular dengan sebutan pondok pesantren. Artinya penyebutan pesantren selalu dibarengi juga oleh kata pondok di awalnya. Lain halnya dengan pesantren, pondok berasal dari bahasa Arab funduq, yang berarti hotel, asrama, rumah, penginapan, dan tempat tinggal sederhana. Di Jawa, pondok dalam konteks pesantren mirip dengan padepokan atau kombongan, yaitu perumahan yang petak-petak dalam kamar, merupakan asrama bagi santri, dan lingkungan tempat para santri menuntut ilmu disebut pesantren [7].

Sedangkan pesantren yaitu asrama tempat para santri atau tempat murid belajar mengaji atau pondok [8]. Menurut Zamakhsyari Dhofier dalam Hj. Binti Maunah perkataan pesantren berasal dari kata santri yang diberi awalan pe di depan dan akhiran an yang berarti tempat tinggal para santri. Sedangkan menurut Nurchlish Madjid dalam Binti Maunah bahwa asal usul kata "santri" dapat dilihat dalam dua pendapat.Pertama, pendapat yang mengatakan bahwa "santri" berasal dari kata sastri, sebuah kata dari bahasa Sansekerta yang artinya melek huruf.Pendapat ini menurut Nurchlish Madjid agaknya didasarkan atas kaum santri adalah kelas literary bagi orang Jawa yang berusaha mendalami agama melalui kitab-kitab bertuliskan dan berbahasa Arab.

Kedua, pendapat yang mengatakan bahwa perkataan santri adalah berasal dari bahasa Jawa, dari kata "cantrik" yang berarti seorang yang selalu mengikuti seorang guru kemana guru pergi dan menetap [9]. Hal ini agaknya didasarkan pada kondisi real sebagian pesantren di mana murid atau santri memang diberikan kewenangan oleh orang tuanya untuk mengaji dan ikut apa dan kemana guru atau kyainya tinggal. Dalam sejarahsejarah Islam juga mengikaskah tentang seorang murid yang selalu mengikuti gurunya dan mengerjakan apa saja yang diperintahkan gurunya, seperti kisah Nabi Khidir dan muridnya, dan kisah lain yang serupa.

Dalam buku Sejarah Pondok Pesantren di Indonesia dijelaskan bahwa secara mudahnya, pondok pesantren adalah lembaga pendidikan Islam yang sekurang-kurangnya memiliki 3(tiga) unsur, yaitu: 1) kyai yang mendidik dan mengajar; 
2) santri yang belajar dan 3) mesjid tempat mengaji [10].

Pesantren sebagai lembaga pendidikan mempunyai watak utama, yaitu sebagai lembaga pendidikan yang memiliki ciri-ciri khas. Dikatakan mempunyai ciri-ciri yang khas karena pesantren memiliki tradisi keilmuan yang berbeda dengan tradisi keilmuan lembaga-lembaga pendidikan lainnya, seperti madrasah atau sekolah [11]. Salah satu ciri utama pesantren sebagai pembeda dengan lembaga pendidikan lain, adalah pengajaran kitab kuning yaitu kitab-kitab Islam klasik yang ditulis dalam bahasa Arab baik yang ditulis oleh para tokoh muslim Arab maupun para pemikir muslim Indonesia [12].

\section{b. Unsur-unsur Pesantren}

Pesantren di Indonesia dan NTB khususnya merupakan lembaga pendidikan Islam yang penyelenggaraan pendidikannya secara umum dengancara non klasikal, yaitu seorang kyai mengajarkan ilmu agama Islam kepada santrisantri berdasarkan kitab-kitab yang ditulis dalam bahasa Arab oleh ulama-ulama abad pertengahan.

Dalam hal ini, sesorang yang memasuki dunia pesantren maka akan menjumpai beberapa unsure pesantren yang meliputi:

1) Kyai, yang guru yang mengajarkan kitabkitab kuning atau literature-literatur keislaman yang digunakan. Selain itu kyai juga sebagai pemangku dan pendidik.

2) Santri, yaitu murid yang belajar pada kyai dan juga tinggal di lingkungan kyai

3) Masjid, yaitu tempat untuk menyelenggarakan pendidikan, shalat berjamaah, dan sebagainya

4) Pondok, yaitu tempat tinggal para santri.

5) Literature-literatur klasik, yaitu kitab kuning yang dipelajari di pesantren [13].

\section{Literatur Keislaman di Pesantren}

a. Literatur atau kitab yang digunakan di pesantren

Kyai dan kitab kuning sebagai literature di pesantren adalah dua hal yang tidak bisa dipisahkan di dunia pesantren.Kedua elemen ini adalah pondasi bagi pembelajaran pesantren dalam memahami ajaran agama yang terkandung dalam al-Qur'an dan hadits. Kitab kuning di pesantren adalah cirri khas yang dimilikinya. Kitab kuning yang digunakan umumnya adalah karangan ulama abad pertengahan yang ditulis dalam bahasa Arab.Adapula yang sudah diterjemahkan ke dalam bahasa melayu atau Indonesia.

Dalam kepustakaan pesantren, kitab kuning yang digunakan terdiri dari berbagai klasifikasi yaitu ilmu-ilmu alat/bantu yang pada dasarnya mencakup cabang tata bahasa Arab tradisional: nahwu (sintaksis), sharaf (infleksi), balaghah (retorika), dan seterusnya [14]. selain itu ada juga tajwid dan logiika. Untuk fiqh meliputi fiqh dan ushul fiqh.doktrin meliputi ushuluddin dan tauhid, juga termasuk ilmu kalam. Untuk tafsir meliputi tafsir, ilmu tafsir, tafsir al-Quran.Al-Hadits dan akhlak dan tasawuf. Teks kitab-kitab ini ada yang sangat pendek, ada juga yang berjilid-jilid. Pengelompokan kitab kuning ini dapat digolongkan dalam tiga tingkat, yaitu: kitab tingkat dasar, kitab tingkat menengah dan kitab tingkat atas [15].

Adapun kitab kuning sebagai literatur keislaman bila dilihat dari penyajian, dapat diklasifikasikan menjadi tiga yaitu, matan, sharah, dan mukhtashar. Kitab matan pada dasarnya adalah kitab asal atau kitab inti. Sebetulnya nama matan itu baru terjadi ketika pada kitab itu dilakukan pengembangan, baik menjadi syarh maupun dalam bentuk hasyiah. Karena itu kitab matan dapat berupa kitab natsr maupun kitab nadzm.

Sharah merupakan kitab yang secara khusus mengulas, memberi komentar dari suatu kitab matan. Kitab syarh ini merupakan kitab perluasan (komentar) dari tingkat pertama, sedangkan kitab yang memperluas lebih lanjut mengenai kitab syarh disebut hasyiah.

Kitab Mukhtashar adalah kitab kuning yang menyajikan materinya dengan cara meringkas materi suatu kitab yang panjang lebar untuk dijadikan karangan singkat tetapi padat. Karena sifatnya yang demikian, kitab ini dengan kata lain merupakan kitab ringkasan yang hanya memuat pokok-pokok masalah [16].

Kitab-kitab kuning yang dipakai di pondok pesantren bila dikelompokkan menurut materi (disiplin /cabang ilmu) dikelompokkan menjadi 11 bidang disiplin ilmu. Adapun cabang ilmu tersebut adalah Nahwu dan Sharf, tajwid, logika, Fiqh, ushul Fiqh, doktrin (tauhid, akidah, ushul al-din), Ulumul Qur'an, tafsir al-Qur'an, Hadits, ulumul Hadits, Akhlak Tasawuf, dan Sejarah Islam.

b. Metode pembelajaran dalam Memahami

Literatur di Pesantren

Metode pembelajaran yang umumnya digunakan dalam konteksnya yang bersifat tradisional adalah sorogan, bandongan, wetonan, dan musyawarah dalam mengkaji kitab-kitab agama yang ditulis oleh para ulama zaman abad pertengahan [17].

Pertama, sorogan, yaitu system pengajaran dengan pola sorogan dilaksanakan dengan jalan santri yang biasanya pandai menyorogkan sebuah kitab kepada kyai untuk dibaca di hadapan kyai itu.Di pesantren besar sorogan dilakukan oleh dua atau tiga orang santri saja, yang biasa terdiri dari keluarga kyai atau santri-santri yang diharapkan di kemudian hari menjadi orang alim.

Kedua, wetonan, yaitu sistem pengajaran dengan jalan kyai membaca suatu kitab dalam waktu tertentu dan santri dengan membaca kitab yang sama mendengarkan dan menyimak bacaan kyai. Dalam system pengajaran seperti ini tidak dikenal adanya absensi.Santri boleh dating, boleh tidak, dan juga tidak ada ujian.System ini biasanya dilakukan dengan belajar secara berkelompok yang diikuti oleh para santri. Mekanismenya, seluruh santri 
mendengarkan kitab yang dibacakan kyai, setelah itu kyai akan menjelaskan makna yang terkandung di dalam kitab yang telah dibacakannya, santri tidak mempunyai hak untuk bertanya terlepas apakah santri-santri tersebut mengerti atau tidak terhadap apa yang telah disampaikan. Adapun kelompok-kelompok kelas yang ada dalam system pengajaran ini, dikenal dengan system halaqah.

Ketiga, bandongan. Dalam system bandongan ini seorang santri tidak harus menunjukkan bahwa ia mengerti terhadap pelajaran yang sedang dihadapi atau disampaikan, para kyai biasanya membaca dan menterjemahkan kata-kata yang mudah.

Keempat, musyawarah yaitu para santri harus mempelajari sendiri kitab-kitab yang ditunjuk dan dirujuk. Kyai memimpin kelas musyawarah seperti dalam suatu seminar dan lebih banyak dalam bentuk Tanya jawab, biasanya hamper seluruhnya diselenggarakan dalam bahasa Arab, dan merupakan latihan bagi para santri untuk menguji keterampilannya dalam menyadap sumber-sumber argumentasi dalam kitab-kitab Islam Klasik [18]. Selain metode yang telah disebutkan di atas ada juga metode lain yang juga biasa diterapkan di pesantren yaitu metode hafalan, muzakarah (pertemuan ilmiah), dan metode Fathul Qulub.

\section{METODE PENELITIAN}

Pada penelitian ini pendekatan yang digunakan yaitu pendekatan penelitian deskriptif kualitatif. Penelitian kualitatif merupakatan pendekatan yang memanfaatkan teori-teori dengan menggali fenomena sosial di lapangan melalui kegiatan observasi, wawancara, cacatan lapangan dan dokumentasi [19]. Pola ini berusaha mendeskripsikan temuan di lapangan dengan mengacu pada teori yang coba dokonfrontasikan dengan fenomena yang ada secara kritis

Pendapat lain mengatakan bahwa pendekatan kualitatif deskriptif merupakan pendekatan yang berusaha menjelaskan fenomena sosial dengan menggali obyek kajian melalui sumber-sumber yang dapat dipertanggungjawabkan secara ilmiah [20].

\section{Sumber Data}

Sumber data merupakan subyek dari mana data penelitian diperoleh dengan mengacu pada tingkat kedekatan dengan kondisi obyektif dari fenomena yang diteliti [21]. Sumber data dalam penelitian ini adalah Tuan Guru (Pembina Pondok Pesantren), Kepala Madrasah Diniyah, para ustaz/ah, dan beberapa santri yang ada di Madrasah Diniyah Nurul Islam Murbaya Kecamatan Pringgarata Lombok Tengah .

\section{Teknik Pengumpulan Data}

a. Teknik observasi

Observasi yang digunakan adalah observasi non partisipan yaitu observasi yang dilakukan dengan cara peneliti tidak terlibat langsung menjadi bagian dari subyek penelitian. Peran peneliti sebagai observer didasarkan pada tujuan untuk memperoleh data-data tentangkondisi pembelajaran di Madrasah Diniyah Nurul Islam Murbaya Kecamatan Pringgarata Lombok Tengah.

b. Teknik interview (wawancara ).

Interview/wawancara merupakan proses tanya jawab antara peneliti dan informan guna menggali informasi terkait fenomena sosial yang terjadi [22]. Dengan demikian Interview/wawancara adalah proses tanya jawab yang dilakukan secara lisan anatar dua orang atau lebih dan mendengarkan secara langsung informasi atau keterangan yang dibutuhkan.

Sasaran interview adalah Tuan Guru (Pembina Pondok Pesantren), Kapala Madrasah Diniyah, para ustaz/ah, dan beberapa santri yang ada di Madrasah Diniyah Nurul Islam Murbaya Kecamatan Pringgarata Lombok Tengah.

c. Teknik Dokumentasi

Dokumentasi adalah suatu kegiatan mengabadikan suatu peristiwa baik dengan cara merekam, menulis, maupun melalui foto [23]. Dokumentasi merupakan laporan tertulis dari suatu peristiwa yang terdiri atas penjelasan atau fikiran terhadap peristiwa dan ditulis dengan sengaja untuk menyimpan dan meneruskan keterangan mengenai peristiwa tersebut.

1) Teknik Analisa Data

Data yang terkumpul selama kegiatan penelitian, harus dianalisis dan diinterpretasikan. Analisis data yaitu proses mengelompokkan, mengurutkan dan menjabarkan data hasil penelitian [24]. Analisis data yang digunakan dalam penelitian ini adalah kualitatif model Miles dan Huberman yaitu:

2) Reduksi Data

Mereduksi data berarti memilih hal-hal yang pokok dengan fokus pada tujuan dari kegiatan penelitian yang dilakukan.

3) Display Data/penyajian Data

Penyajian data merupakan upaya menjabarkan data secara terorganisir yang disusun dalam pola hubungan yang saling berkaitan sehingga mudah dipahami.

4) Verifikasi data/ kesimpulan awal

Verifikasi data yaitu upaya membuat kesimpulan awal yang didasarkan pada pemahaman dan penemuan fenomena sosial yang menjadi batasan masalah dalam penelitian [25]. Fenomena yang terjadi akan dapat disimpulkan melalui data yang diperoleh di lapangan.

\section{PEMBAHASAN}

\section{Gambaran Singkat Madrasah Diniyah Nurul Islam Dasan Baru, Murbaye}

Dalam konteks pendidikan Islam di NTB dan lebih khususnya di Lombok, madrasah diniyah merupakan lembaga pendidikan Islam non formal yang umumnya diselenggarakan di aula-aula atau gedung di mana kiai (Sasak: tuan guru) dan santri tinggal. Dalam proses pembelajaran keislaman 
biasanya di selenggarakan di waktu-waktu luar sekolah. Madrasah diniyah merupakan lembaga yang bernaung atau menjadi bagian dari sebuah pondok pesantren.Maka, pada dasarnya program diniyah adalah salah satu dari kegiatan-kegiatan pembelajaran di pondok pesantren selain dari pengajian umum atau pembelajaran tahfiz.

Dalam perkembangannya, hampir seluruh pondok pesantren yang pada masa-masa klasik merupakan lembaga non formal yang khusus mengajarkan keIslaman, sekarang menerapkan juga lembaga pembelajaran formal seperti Madrasah Ibtidaiyyah, Tsanawiyah, Aliyah, bahkan sampai perguruan tinggi.Dalam hal ini materi-materi yang diajarkan tidak hanya materi yang berkaitan dengan keislaman saja, melainkan mjuga materi umum dengan mengikuti kurikulum yang telah ditetapkan oleh pemerintah. Sebagaimana yang dikatakan oleh Ustaz Halabi selaku pengajar pada madrasah diniyah dan juga madsarah Aliyah mengatakan:

"Kurikulum yang kami gunakan untuk pendidikan formal, misalkan di Tsanawiyah dan Aliyah adalah kurikulum yang sudah ditetapkan di pusat atau pemerintah, kami tidak mengubah kurikulum tersebut meskipun untuk pelajaran agama Islam. Buku-buku yang kami gunakan juga standar atau sesuai kurikulum.Nah, kalau di diniyah, kurikulum yang digunakan adalah sesuai dengan cirri pondok pesantren kami yaitu menggunakan kitabkitab yang kebanyakan ditulis oleh ulama klasik dan sesuai dengan akidah yang dibawa Asy'ariyah".

Hal inilah yang terjadi di pondok pesantren Nurul Islam Dasan Baru, Desa Murbaye, Kec. Pringgarata, Lombok Tengah, NTB. Madrasah diniyah yang ada di sana merupakan bagian dari program pondok pesantren yang memiliki orientasi pada pengembangan para santri baik dalam pengetahuan keIslamannya, karakternya, maupun akhlaknya terhadap sesama dan terhadap Tuhan.

Pondok pesantren Nurul Islam Dasan Baru, Murbaye menganut system pesantren yang merupakan lembaga gabungan antar sistem pondok dan pesantren yang memberikan pendidikan dan pengajaran agama Islam dengan sistem bandongan, sorogan atau wetonan dengan para santri disediakan pondokan atau pun merupakan santri kalong yang dalam istilah pendidikan modern memenuhi kriteria pendidikan non formal serta menyelenggarakan juga pendidikan formal berbentuk madrasah dan bahkan sekolah umum dalam berbagai bentuk tingkatan dan aneka kejuruan sesuai dengan kebutuhan masyarakat masing-masing

Terkait dengan pengembangan tersebut, maka madrasah diniyah Dasan Baru, Murbaye mengembangkan berbagai hal yang menunjang tercapainya tujuan tersebut, yang meliputi peningkatan sarana dan prasarana, sumber daya manusia (pengajar: untaz/ustazah, kiai), literaturliteratur yang digunakan sebagai modal untuk mewujudkan santriwan/santriwati yang islami, berakhlak mulia, dan berkarakter. Selain itu, juga dilakukan sedikit perubahan struktur dalam kepengurusan pondok pesantren.

\section{Literatur Keislaman yang digunakan di Madrasah Diniyah Nurul Islam}

Salah satu keunikan dari pondok pesantren adalah literatur yang digunakan. Eksistensi pondek pesantren termasuk madrasah diniyah sebagai madrasah awal tempat pembelajaran dasar tentang keislaman dapat berjalan dan kuat hingga saat ini adalah karena literatur yang digunakan. Literature tersebut berupa kitab kuning yang umumnya dikarang oleh ulama klasik dan biasanya berasal dari timur tengah atau kitab berbahasa Arab. Adapula yang berasal dari Indonesia namun jumlahnya tidak sebanyak yang dikarang oleh ulama Arab.

Di Indonesia kitab kuning yang tidak memiliki harakat dan memang warna kertasnya kuning ini juga disebut sebagai kitab gundul. Kitab ini merupakan kitab wajib yang digunakan oleh pondok pesantren di Indonesia tidak terkecuali pondok pesantren Nurul Islam Dasan Baru, Murbaye. Kitab kuning merupakan cirri khas dari semua pondok pesantren.Sebagaimana yang telah dijelaskan sebelumnya bahwa pesantren dikatakan sebagai pondok pesantren apabila memiliki hal-hal berikut. Yaitu kiai (tuan Guru), santri, pondok, masjid, dan kitab kuning. Kesemuanya ini harus berjalan sehingga proses transmisi dan internalisasi nilai-nilai keislaman dapat berjalan sesuai harapan.

Literatur keislaman yang berupa kitab kuning di pesantren memiliki daya magnet yang kuat terhadap tipe pondok pesantren dan kemajuannya. Pondok pesantren tertentu dikatakan sebagai pondok pesantren salaf karena kitab atau literature yang digunakan bernuansa atau berisi ajaran-ajaran salaf. Pondok pesantren tradisional dikatakan demikian karena kitab yang digunakan adalah kitab-kitab yang dikarang oleh ulama-ulama tradisonal atau klasik, yang dalam hal ini merujuk pada mazhab yang empat. Dan pondok pesantren modern dikatakan demikian karena literature yang digunakan juga adalah literature kontemporer yang umumnya tidak merujuk atau mengaju pada mazhab tertentu.

Oleh karena itu kehadiran literatur kitab kuning ini sangat membantu masyarakat dalam menentukan pondok pesantren mana yang cocok buat anak atau kerabatnya, ataupun menurut afiliasi dan aliran keagamaan yang dianutnya. Sehingga dengan demikian literatur yang digunakan di pondok pesantren antara yang satu dengan yang lain bisa berbeda, atau sebagian sama dan sebagian berbeda. Dalam hal perbedaan ini, penulis mewawancarai ustaz Halabi dan Ustaz Ahmad Zazri kemudian 
menjelaskan bahwa perbedaan ini memang didasarkan pada orientasi keagamaan atau aliran keagamaan yang dianutnya. Pondok pesantren salaf, tradisional, dan modern memiliki perbedaan dalam hal literature yang digunakan terutama dalam hal akidah atau tauhid. Meskipun ada berberapa kitab yang sama namun itu tidaklah banyak.

Kitab kuning yang digunakan di Madrasah Diniyah Nurul Islam Dasan Baru, Murbaye sebagian besar adalah kitab klasik yang dikarang oleh ulama terdahulu pada abad pertengan atau abad 19. Ada juga beberapa kitab yang lebih baru atau kontemporer namun jumlahnya sangat sedikit, yaitu 1:10. Kitab kuning tersebut umumnya di karang oleh ulama Arab dan ada pula karangan ulama Indonesia.Namun sebagian besar dari karangan ulama Arab. Selain kitab kuning tipe di atas tidak ada kitab lain yang digunakan baik untuk pengajian umum, pengajian diniyah, ataupun pada santapan rohani. Hal ini didasarkan pada latar belakang mazhab pondok pesantren Nurul Islam yang tetap memgang empat mazhab untuk Fiqh, Asy'ariyah dan maturidiyah untuk tauhidnya, dan al-Gazali untuk tasawufnya. Senada dengan penjelasan di atas, ustaz Halabi dan Tuan Guru Mustahik Abadi yang penulis wawancarai mengatakan:

" Kita menggunakan kitab-kitab tradisional atau klasik yang ditulis oleh ulama terdahulu untuk membentengi kita dari paham salaf wahabi ataupun paham-paham yang menjurus ke ekstrimis. Kitab yang kita gunakan adalah kitab yang merujuk pada empat mazhab untuk fiqhnya, asy'ariyah untuk tauhidnya, dan akhlak tasawuf dari kitab yang merujuk pada pemahaman al-Gazali. Semua itu tetap kita gunakan agar keislaman para santri dan masyarakat sekitar terjaga dari paham salafi wahabi”.

Meskipun secara keorganisasian pesantren Nurul Islam Dasan Baru tidak berafiliasi pada salah satu organisasi keagamaan, namun dapat dikatakan bahwa pondok pesantren ini beraliran sunni. Ini terlihat jelas dari literature yang digunakan sebagai mana paparan di atas.

Adapun literature-literatur yang digunakan dapat dijabarkan sebagai berikut:

a. Dilihat dari segi penyajian, literatur yang

digunakan berupa kitab-kitab matan, syarah,

mukhtashar, dan terjemahan.

Untuk matan digunakan pada santri yang masih awal tingkatannya. Kitab matan ini contohnya adalah matan al-ajrumiyyah untuk pelajaran Nahwu, amtsilatut Tashrifiyah untuk Sharf, Matan Taqrib untuk fiqh, matan Sanusi untuk tauhid, dan matan Safinah untuk praktek ibadah.

Untuk syarah digunakan pada santri awal dan menengah. Kitab syarah ini contohnya adalah syarah dahlan untuk Nahwu, syarah Kailani untuk Syaraf, syarah jurumiyah, Kafrawi untuk Nahwu,
Fathul Qarib untuk Fiqh, Bajuri, Uqudulujjain, kifayatul Awam untuk tauhid, dan lain lain.

Mukhtashar atau ringkasan yang digunakan adalah Alfiyah ibn Malik yang merupakan ringkasan dari kitab al-Kafiyah atau kitab $L u b b$ al-Ushul yang meringkas kitab Jam' alJawami' karya as-Subki. Atau karya paling akhir dari jenis ini ialah Mukhtashar Ibn Katsir karya Ali al-Shabuni yang merupakan ringkasan dari kitab tafsir Ibn Katsir.

Literatur keislaman dengan penyajian terjemahan juga digunakan oleh Madrasah Diniyah Nurul Islam Dasan Baru, Murbaye.Terjemahan di sini maksudnya adalah dari bahasa Arab ke bahasa Indonesia.Atau kitab versi Indonesia.Untuk tafsir al-Qur'an misalnya menggunakan Tafsir Jalalain edisi Indonesia, penerjemah Najib Junaidi.untuk Fikih yang bersifat perluasan (cabang) contohnya adalah Fikih masjid, penulis Huri Yasin Husain dengan penerjemah Khalifurrahman Fath dan Fathurrahman Nizar az-Zainaby. Untuk hadits juga ada yang menggunakan kitab terjemahan seperti Ringkasan Shahih Bukhari oleh Muhammad Nashiruddin Al-Albani dengan penerjemah Rahmatullah, Fadhail Rahman, dan Masrur Huda.

Dapat disimpulkan di sini bahwa Madrasah Diniyah Nurul Islam Dasan Baru, Murbaye menggunakan kitab dari berbagai versi menurut penyajiannya. Hal ini dilakukan untuk mempermudah lancarnya pembelajaran agama pada anak didik. Sehingga dalam memahami isi kandungan kitab ustaz atau ustazah menggunakan beberapa versi. Begitu juga kitab yang dipegang oleh santri baik santriwan ataupun santriwati. Mereka direkomendasikan untuk memiliki kitab baik kitab versi Arab yang berupa matan, syarah, dan mukhtasahar serta versi Indonesia atau kitab terjemahan.

Kitab-kitab tersebut meskipun ada yang berupa terjemahan namun tidak terlepas dari materi atau kandungan yang ada dalam kitab. Semua kitab tidak boleh terlepas dari rujukan ulama atau pengarang terdahulu terutama untuk fikih dan tauhid.

b. Dilihat dari cabang atau disiplin ilmu, maka literatur keislaman yang digunakan di Madrasah Diniyah Nurul Islam Murbaye secara lebih rinci pada table berikut:

Tabel 1

Literatur keislaman yang digunakan

BIDANG NAMA KITAB PENGARANG

ILMU

$\begin{array}{cll}\begin{array}{c}\text { Fiqih } \\ \text { dan }\end{array} & \text { Safinah an-Naja } & \text { Salim bin Sumair al- } \\ \text { Ushul } & \text { Fath al-Qarib } & \text { Hadlramy } \\ & \text { Bajuri (Syarah Fath al- } & \text { Ibrahim al-Bajuri } \\ & \text { Qarib) } & \\ & \text { Minhaj ath-Thalibin } & \text { Imam Nawawi } \\ & \text { Fath al-Mu'in } & \text { Zainuddin bin Abd al- } \\ & & \text { Aziz bin Zainuddin al- } \\ & & \text { Malibari }\end{array}$




\begin{tabular}{|c|c|c|}
\hline & Uqud al-Lujjain & $\begin{array}{l}\text { Muhammad Nawawi } \\
\text { al-Bantani }\end{array}$ \\
\hline & Fiqh al-Wadhih & Mahmud Yunus \\
\hline & Kasyifah as-Saja & $\begin{array}{ll}\text { Fadhil Abi al-Muthi } \\
\text { Muhammad } \\
\text { al-Jawi }\end{array}$ \\
\hline & Syarah Kasyifah as- & Nawawi bin Umarat \\
\hline & Saja & $\begin{array}{l}\text { Tanari al-Bantani al- } \\
\text { Jawi }\end{array}$ \\
\hline \multirow[t]{7}{*}{ Tauhid } & Khamsatu Mutun & (Mukhtashar dari Kitab \\
\hline & & $\begin{array}{ll}\text { Matan Bajuri, } & \text { Matan } \\
\text { Jauharah, } & \text { Matan } \\
\text { Sanusi, } & \text { Matan } \\
\text { Kharidah, dan } & \text { Matan } \\
\text { Syaebaniyah) } & \end{array}$ \\
\hline & Tijan ad-Darari & $\begin{array}{l}\text { Ahmad Nawawi al- } \\
\text { Jawi }\end{array}$ \\
\hline & Fath al-Majid & $\begin{array}{l}\text { Ahmad Nawawi al- } \\
\text { Jawi }\end{array}$ \\
\hline & Kifayah al-Awam & Muhammad bin \\
\hline & & Muhammad al-Fadholi \\
\hline & Syarqawi al-Hudhudi & Abdullah asy-Syarqawi \\
\hline \multirow{4}{*}{$\begin{array}{c}\text { Tafsir } \\
\text { al- } \\
\text { Qur'an }\end{array}$} & Tafsir Jalalain & Jalaluddin Muhammad \\
\hline & & bin Ahmad bin \\
\hline & & $\begin{array}{l}\text { Muhammad al-Mahalli } \\
\text { dan Jalaluddin } \\
\text { Abdirrahman bin Abu } \\
\text { Bakr as-Suyuthi }\end{array}$ \\
\hline & $\begin{array}{l}\text { Tafsir Ayat Ahkam as- } \\
\text { Shabuni (Terjemahan) }\end{array}$ & $\begin{array}{l}\text { Muhammad Ali ash- } \\
\text { Shabuni (Terj.) oleh } \\
\text { Mu'ammal Hamidy dan } \\
\text { Imran A. Manan }\end{array}$ \\
\hline \multirow{4}{*}{$\begin{array}{l}\text { Tafsir } \\
\text { Hadits }\end{array}$} & Bulugul Maram & Ibnu Hajar al-Asqalani \\
\hline & $\begin{array}{l}\text { Ibanah al-Ahkam } \\
\text { Arba'in }\end{array}$ & $\begin{array}{l}\text { Abi Abdillah as-Salam } \\
\text { Abu Zakaria Yahya al- } \\
\text { Nawawi }\end{array}$ \\
\hline & Tanqih al-Qaul & Nawawi al-Bantani \\
\hline & $\begin{array}{l}\text { Ringkasan Shahih } \\
\text { Bukhari (Terjemahan) }\end{array}$ & $\begin{array}{l}\text { Rahmatullah dan } \\
\text { Fadhail Rahman }\end{array}$ \\
\hline \multirow[t]{2}{*}{$\begin{array}{l}\text { Akhlak } \\
\text { Tasawuf }\end{array}$} & Ta’lim al-Muta'allim & $\begin{array}{l}\text { Burhan al-Islam az- } \\
\text { Zarnuji }\end{array}$ \\
\hline & $\begin{array}{l}\text { Al-Akhlaq lil Banin } \\
\text { dan al-Akhlaq lil- } \\
\text { Banat }\end{array}$ & Umar bin Ahmad Barja \\
\hline \multirow[t]{2}{*}{$\begin{array}{l}\text { Sejarah } \\
\text { Nabi }\end{array}$} & $\begin{array}{l}\text { Khulashah } \quad \text { Nurul } \\
\text { Yaqin }\end{array}$ & 'Umar Abd al-Jabbar \\
\hline & Kitab al-Barzanji & Ja'far al-Barzanji \\
\hline \multirow[t]{6}{*}{$\begin{array}{c}\text { Ilmu } \\
\text { Alat } \\
\text { (Tata } \\
\text { Bahasa } \\
\text { Arab) }\end{array}$} & $\begin{array}{l}\text { Matn al-Ajrumiyyah } \\
\text { (Nahwu) }\end{array}$ & $\begin{array}{l}\text { Abu Abdillah } \\
\text { Muhammad bin } \\
\text { Muhammad bin Dawud } \\
\text { ash-Shinhaji }\end{array}$ \\
\hline & Sharh Dahlan (Nahwu) & Ahmad Zaini Dahlan \\
\hline & $\begin{array}{l}\text { Nahw al-Wadhih } \\
\text { (Nahwu) }\end{array}$ & $\begin{array}{l}\text { Ali al-Jarimy dan } \\
\text { Mushthafa Amin }\end{array}$ \\
\hline & $\begin{array}{l}\text { Al-Kawakib ad- } \\
\text { Durriyah }\end{array}$ & Abdullah bin Ahmad \\
\hline & Kailani (Syarf) & $\begin{array}{l}\text { Abu Hasan Ali bin } \\
\text { Hisyam al-Kailani }\end{array}$ \\
\hline & $\begin{array}{l}\text { Qawaid al-Lughah al- } \\
\text { Arabiyyah }\end{array}$ & Hifni Nazhif, dkk \\
\hline
\end{tabular}

\section{Metode Pembelajaran yang Diterapkan dalam Memahami Literature-Literatur Keislaman di Madrasah Diniyah Nurul Islam, Dasar Baru, Murbaye.}

Metode pembelajaran di Madrasah Diniyah Nurul Islam, Dasan Baru, Murbaye merupakan metode pengajaran yang bersifat tradisional. Yaitu pembelajaran yang umumnya digunakan oleh pondok pesantren-pondok pesantren yang ada di Indonesia seperti Sorogan, Wetonan, musyawarah, Hafalan, dan Fath al-Qulub.

Metode-metode di atas erat kaitannya dengan tipologi pesantren yaitu bersifat tradisionlal dengan ciri-ciri (karakteristik) kyai (Tuan Guru), santri baik santri yang tinggal di dalam pesantren (lingkungan Tuan Guru) ataupun santri kalong (yang tinggal di luar kawasan Tuan Guru), dan masjid (sebagai sarana pembelajaran) sebagai unsur penting dalam pesantren tradisional. Metode pembelajaran sebagaimana yang disebut di atas adalah metode yang dipakai dalam rangka internalisasi pendidikan Islam kepada seluruh santri. Di samping itu sebagai karakteristik pendidikan tradisional yang masih berlangsung hingga kini meskipun kehadiran metode yang lain semakin membanjir dengan media teknologi yang semakin canggih.

Metode pembelajaran seperti di atas sebagaiman yang dijelaskan oleh Ustaz Halabi yang penulis wawancarai tetap dipakai untuk melanggengkan nuansa dan karakteristik pondok pesantren yang membawa misi penyebaran Islam yang cenderung tradisonal atau yang dibawa oleh ulama-ulama terdahulu khususnya pada masa pertengahan. Penjabaran dari masing-masing metode pembelajaran di atas adalah sebagai berikut:

\section{a. Sorogan}

Sistem pengajaran dengan pola sorogan dilaksanakan dengan jalur sebagai berikut: pertama-tama santri yang pandai menyodorkan sebuah kitab kepada tuan guru kemudian si santri membacakan isi kitab tersebut. Kedua, tuan guru menyimak isi bacaan si santri yang kemudian meluruskan atau menjelaskan hal-hal yang belum jelas dari bacaan si santri. Biasanya di pondokpondok pesantren besar, sistem sorogan ini dihadiri atau terdiri dari keluarga kyai atau tuan guru atau santri-santri yang diharapkan menjadi orang alim ataupun penerus di kemudian hari.

b. Wetonan

Di Madrasah Diniyah Nurul Islam Dasan Baru, sistem Wetonan disebut juga dengan sistem duduk bersila. Yaitu sistem pengajaran dengan jalan tuan guru membaca suatu kitab yang kemudian didengar dan disimak oleh para santri dengan menggunakan kitab yang sama yang dibaca oleh tuan guru.

Pengajaran melalui wetonan ini tidak mengenal adanya teknis administratif sebagaimana pengajaran di kelas yang bersifat formal seperti absensi ataupun ujian. Sistem seperti ini dilakukan secara berkelompok yang diikuti oleh para santri. Suasana yang dibangun dalam pembelajaran seperti ini adalah suasana 
kekeluargaan di mana antara guru dan santri merasa sangat dekat dan kadang-kadang dalam proses pembelajaran diselingi oleh canda ringan untuk menghangatkan suasana.

Alur dari sistem wetonan ini adalah seluruh santri mendengarkan kitab yang dibacakan oleh tuan guru/ustaz/ustazah, setelah itu tuan guru/ustaz/ustazah akan menjelaskan makna yang terkandung dalam kitab tersebut. Biasanya santri tidak diperkenankan untuk bertanya meskipun kemungkinan ada yang mengerti atau tidak mengerti. Akan tetapi praktek dalam pembelajaran di Nurul Islam Dasan Baru, santri juga bertanya ketika si santri tersebut mendapat penjelasan yang kurang jelas. Kelompokkelompok kelas yang tergabung dalam sistem pembelajaran wetonan ini disebut dengan sistem halaqah.

c. Musyawarah

Musyawarah yaitu sistem pembelajaran dengan jalan para santri mempelajari sendiri kitab-kitab yang sudah ditunjuk dan dirujuk. Dalam hal ini tuan guru berperan sebagai moderator atau yang memimpin kelas. Sistem ini tidak jauh beda dengan suatu seminar di mana tanya jawab merupakan cara yang dominan yang dipakai. Adapun bahasa yang digunakan dalam musyawarah ini adalah bahasa Arab, hal ini bermaksud sebagai latihan bagi para santri dalam menguju keterampilannya dan menyadap sumbersuber yang digunakan sebagai argumentasi dari kitab-kitab kuning (klasik).

Adapun di Madrasah Diniyah Nurul Islam juga menggunakan sistem musyawarah ini, tapi terkadang menggunakan bahasa nasional (bahasa Indonesia). Hal ini disebabkan oleh orientasi pembelajaran yang lebih konsen kepada pengajian dan pengkajian kitab kuning secara tekstual, bukan bahasa Arab secara verbal. Kemampuan para santri juga lebih kepada kemampuan membaca adan mengurai kitab-kitab kuning dari pada berbicara menggunakan bahasa Arab. Hal inilah yang menyebabkan musayawarah dalam kelas lebih banyak menggunakan bahasa Indonesia.

d. Hafalan

Metode hafalan digunakan untuk mendorong para santri lebih giat lagi dalam mempelajari kitab-kitab yang dirujuk. Adapun kitab-kitab yang menjadi materi hafalan adalah kitab-kitab pengantar atau kitab yang digunakan pada kelas awal seperti Safinah an-Najah, Matn Taqrib, Matn al-Ajrumiyyah, dan lain-lain. Mekanismenya adalah tuan guru/ustaz/ustazah menunjuk kitab yang akan dihafal, kemudian para santri menyetorkan hafalannya di hadapan tuan guru/ustaz/ustazah sampai mana hafalannya tersebut.

Sebenarnya dalam sebagian pendapat metode hafalan ini sudah tidak cocok diterapkan dalam pembelajaran karena akan berdampak pada analisis atau pengkajian yang kurang dari suatu materi. Para santri atau murid lebih banyak menerima informasi atau isi luar dari materi di dalam kitab dari pada mengkaji atau menganalisa makna yang terkandung dalam kitab yang dirujuk. Namun, menurut penulis metode hafalan akan sangat efektif bila disertai dengan analisa atau pengkajian yang detail terhadap suatu materi yang dihafal. Sehingga dalam hal ini para santri tidak hanya paham secara tekstual juga memahami bisa memahami makna secara kontekstual.

e. Fath al-Qulub

Fath al-Qulub dalam konteks MD Nurul islam Dasan baru diartikan sebagai metode pembelajaran dengan cara atau bentuk pengajian. Yaitu tuan guru menyampaikan suatu materi dalam satu tema tertentu kepada para santri di mana santri hanya mendengarkan dan menyimak apa yang yang disampaikan oleh tuan guru. Biasanya ini dilakukan pada pagi hari sebelum santri masuk ke kelas formal (sekolah). Beberapa pondok pesantren di Lombok dan termasuk di Nurul Islam menyebut Fath al-Qulub dengan Santapan Rohani.

\section{E. KESIMPULAN}

Dari penjelasan tentang literatur Keislaman dalam pendidikan pondok pesantren di atas, penulis dapat memberikan kesimpulan sebagai berikut:

1. Literatur-literatur yang digunakan di Madrasah Diniyah Nurul Islam, Dasan Baru, Murbaye, Lombok Tengah merupakan kitab-kitab yang umumnya digunakan oleh pondok-pondok pesantren tradisional di Indonesia. Pondok tradisional yang dimaksud mengacu pada pondok pesantren yang menganut atau mengikuti ulama-ulama terdahulu khususnya ulama abad pertengahan. Dalam konteks Indonesia pesantren ini biasa disebut pesantren tradisional. Oleh karena itu kitab-kitab yang digunakan adalah kitab-kitab yang

Dikarang oleh ulama tradisional pada abad pertengahan seperti imam Syafi'i untuk Fiqh, Asy'ari untuk Tauhid, al-Ghazali untuk Akhlak Tasawuf.

2. Metode pembelajaran yang diterapkan dalam memahami literatur keislaman yaitu metode yang disesuaikan dengan tipe dan karakteristik pondok pesantren tersebut. Adapun metode yang digunakan di Madrasah Diniyah Nurul Islam Dasan Baru ialah metode Sorogan, Wetonan, Musyawarah, Hafalan, dan Fath al-Qulub. Metode ini disesuaikan misi pondok pesantren yaitu sebagai tempat mentranfer nilai-nilai keislaman pada santri. Hal ini sesuai dengan tipe pondok pesantren yang bersifat tradisional dengan karakteristik tuan guru sebagai panutan utama dalam pendidikan, santri sebagai sasaran internalisasi nilai-nilai keislaman sebagaimana ajaran ulama tradisional, dan masjid sebagai sarana pengajian dan pengkajian selainaula pondok pesantren dan berugak (bahasa jawa:cakruk). 


\section{DAFTAR RUJUKAN}

[1] Abdurrahman Wahid, Menggerakkan Tradisi: Esaiesai Pesantren, (Yogyakarta: LKiS, 2001), hlm. 157.

[2] Binti Maunah, Tradisi Intelektual Santri dalam Tantangan dan Hambatan Pendidikan Pesantren di Masa Depan, Yogyakarta, Teras: 2009, h. 1.

[3] Burhan Bungin, Penelitian Kualitatif (Jakarta: Surya Kencana, 2007), 121.

[4] Departemen Pendidikan Nasional, "Kamus Besar Bahasa Indonesia" Pusat Bahasa (Jakarta, Gramedia Pustaka Utama: 2008), hal. 1064.

[5] Hj. Binti Maunah, Tradisi Intelektual Santri,...

[6] Kuttab merupakan pusat pengajaran paling tua di kalangan kaum muslimin.Bahkan ada yang mengatakan dunia Arab telah mengetahuinya sebelum kedatangan Islam.Kuttab menyerupai madrsah ibtidaiyah pada masa sekarang. Lihat Raghib as-Sirjani, Sumbangan Peradaban Islam pada Dunia (Jakarta, Pustaka al-Kautsar: 2011)

[7] Kitab Kuning, Pesantren, dan Tarekat, Martin Van Bruinessen (Yogyakarta, Gading Publishing: 2012)

[8] Lexy J. Moleong, Metodologi penelitian Kualitatif (Bandung : PT Remaja Rosdakarya, 2007)

[9] Madrasah Diniyah (MD) merupakan pendidikan Islam non-formal yang berfungsi sebagai tempat pembelajaran agama Islam yang bersifat mendasar.Hal ini terlihat dari materi-materi kajian berupa kitab kuning yang bentuknya masih Syarh atau matan (pengantar).

[10]Sorogan yaitu model pengajaran dengan cara si santri membacakan kitab kepada sang kiai, kemudian kiai menyimak dan mengarahkan atau membetulkan bila ada kesalahan. Bandongan yaitu pengajaran dengan cara kiai membacakan dan menterjemahkan kitab-kitab yang dikajinya. Dalam hal ini santri tidak harus mengerti atau memahami dahulu kitab yang dikaji. Wetonan adalah system yang setara dengan bandongan yaitu dengan cara kiai membaca kitab yang dikaji, dan santripun membaca kitab yang sama dengan kiai sembari mendengar dan menyimak bacaan kiai.

[11] Martin van Bruinessen, kitab Kuning, Pesantren, dan Tarekat (Yogyakarta, Gading : 2012),

[12]Marwan Sarijo, dkk. 1982. Sejarah Pondok Pesantren di Indonesia. Jakarta: Penerbit Dharma Bhakti

[13]Pengertian kitab kuning seperti ini sengaja penulis melakukan mengingat realitas di pesantren, bahwa kitab-kitab yang diajarakan di pesantren itu meliputi karya-karya pemikir muslim Indonesia, seperti karya Syekh Nawawi Banten

[14]Prasodjo dalam $\mathrm{Hj}$. Binti Maunah, Tradisi Intelektual Santri dalam Tantangan dan Hambatan Pendidikan Pesantren di Masa Depan (Yogyakarta, Teras: 2009)

[15] Sugiyono, Memahami Penelitian Kualitatif (Bandung: CV Alfabeta, 2010)
[16]Suharsimi Arikunto, Prosedur Penelitian Pendekatan Praktis (Jakarta: Rineka Cipta, 2002)

[17]Sembodo Ardi Widodo, dkk., Struktur Keilmuan Pesantren : Studi Komparatif antara Pesantren Tebuireng Jombang dan Mu'allimin Muhammadiyah Yogyakarta, Ringkasan Laporan Hasil Penelitian Tahun 2002, diunduh dari http://www.ditpertais.net/istiqro/isto2-01.asp dikases Juli 2017 pukul 22.30 WIB.

[18]Tim Peneliti Keagamaan, Kasus-Kasus...

[19]Zamakhsyari Dhofier, Tradisi Pesantren: Studi Pandangan Hidup Kyai dan Visinya Mengenai Masa Depan Indonesia, Jakarta, LP3ES: 2011 